\title{
Genetic transmission of colorectal cancer: exploratory data analysis from a population based registry
}

The Colorectal Cancer Study Group of the University of Modena and the Health Care District 16, Istituto di Patologia Medica, Università di Modena, Italy.

$M$ Ponz de Leon

$G$ Zanghieri

R Sassatelli

C Sacchetti

Dipartimento di Biologia Evolutiva, Università di Ferrara,

Italy.

C Scapoli

I Barrai

Correspondence to Professor Barrai, Dipartimento di Biologia Evolutiva, Via Luigi Borsari 46, 44100 Ferrara, Italy.

Received 20 May 1991.

Revised version accepted 9 January 1992.

\author{
Maurizio Ponz de Leon, Chiara Scapoli, Gianni Zanghieri, Romano Sassatelli, \\ Carla Sacchetti, Italo Barrai
}

\begin{abstract}
Classical segregation analysis was conducted on 605 families of probands with colorectal carcinoma ascertained through the Cancer Registry of the Province of Modena in Italy. The families were classified as 28 suspected hereditary non-polyposis colorectal cancer (HNPCC) syndromes and 577 presumed nonHNPCC. In 11 of these, both parents had colorectal carcinoma, in 130 one parent was affected, and in 436 both parents were normal. In the suspected HNPCC families, segregation was compatible with dominant transmission of susceptibility to carcinoma. In families with one parent affected, the segregation frequency was almost exactly equal to the frequency of segregation in families where both parents were normal. The model of dominant transmission of susceptibility through a major gene with greatly reduced penetrance in heterozygotes fitted the data acceptably.
\end{abstract}

The contribution of heritable factors to the pathogenesis of large bowel neoplasms has been extensively investigated but, with the exception of a few well defined conditions, is not clearly understood. There is no doubt that adenomatosis coli and related syndromes show features of autosomal dominant transmission. ${ }^{1-5}$ A similar mendelian (autosomal dominant) basis has been described for hereditary nonpolyposis colorectal cancer (HNPCC).$^{67}$

Besides these well characterised syndromes, familial aggregates of colorectal (and other) tumours have frequently been reported and usually attributed to polygenic inheritance. ${ }^{8-10}$ In a recent investigation, Lynch et al suggested that about $5 \%$ of all colon cancers might be the result of hereditary monogenic factors, approximately 10 to $15 \%$ could be attributed to polygenic inheritance, and that the remainder had to be considered truly sporadic cases. ${ }^{1112}$ Although partially confirmed by other authors, these views have recently been challenged by Burt et $a l^{13}$ and CannonAlbright et al. ${ }^{14}$

In a recent review on colon cancer genetics, Veale $^{15}$ suggested that one of the most appropriate ways to obtain more information on this subject was to carry out population based studies in centres with cancer registries.

This kind of approach has been possible in Modena, Italy, where a Colorectal Cancer
Registry (CCR) was instituted in 1984 with the specific objective of studying the familial occurrence of cancer in registered patients and of identifying kindreds with hereditary colorectal tumours. ${ }^{1617}$

The purpose of the present investigation was to carry out segregation analyses on the whole series of patients registered in the period between 1984 and 1988 and on their first degree relatives. Using segregation analysis in colon cancer may be considered exploratory, since it is obviously a complex entity. However, in this work our minimal objective was to discriminate between transmission models and to estimate average risks. Classical segregation analysis does not include the multifactorial alternative which has to be tested separately. It does not allow for different risk categories dependent on age and sex and estimates different parameters for each assumed mating type. Nevertheless, it permits testing a wealth of simple genetic hypotheses, from which useful indications can be obtained.

\section{Materials and methods}

PATIENTS

The study was carried out in the province of Modena in Italy on patients listed in the CCR of the Local Health District 16 during the period 1984 to 1988 . The general organisation of the CCR has previously been described in detail. ${ }^{1618}$ The Health Care District 16 includes Modena and 10 smaller centres comprising a total of 263546 inhabitants (127026 males, 136520 females, census 1981). Patients with colorectal cancer (proven by biopsy in $93.5 \%$ of cases) or their close relatives or both were interviewed during admission to hospital in one centre. The patient was considered as the proband or index case. Besides personal, clinical, and pathological data, an accurate pedigree was traced for each patient and the main causes of morbidity and mortality among first degree relatives were recorded.

The group under study comprised 677 patients registered for colorectal cancer between 1984 and 1988. Annual incidence rates ranged between 51.4 and 53.5 cases per 100000 inhabitants per year. Six hundred and five out of the 677 patients $(89.4 \%)$ gave detailed information on cancer occurrence among first degree relatives, but 72 were excluded because of poor clinical history, refusal to collaborate, or death within a few days of admission to hospital (which prevented an accurate definition of the pedigree). Thus, 
segregation analysis was carried out in 605 sibships with 873 affected subjects, that is, 605 probands plus 168 sibs with cancer.

One of the main drawbacks of the study was the inability to verify, by death certificates or clinical charts, all the diagnoses of cancer in relatives; in the $41 \%$ of those in whom it was possible, however, good agreement was found between information taken by the interviewers and the data recorded in official certificates. ${ }^{17}$ Since the study was limited to first degree relatives, as suggested by other authors, we believe that bias owing to inability to verify all cancer diagnoses should be low. ${ }^{19}$

To summarise, at the end of 1988 we had 605 families with at least one subject affected by colorectal cancer and information concerning tumour status (colorectal or other cancer) of first degree family members.

\section{COMPLETENESS OF REGISTRATION}

Overregistration of cases seems improbable in our study since (1) we gathered a relatively small number of patients and (2) the study was limited to the large bowel. Underregistration is more difficult to evaluate and to control. Incomplete reporting of cases, inaccuracy of diagnosis, and referral of patients to medical units outside the district are the commonest causes of loss of cases. In our opinion, underregistration was negligible because (1) the incidence of colorectal cancer in 1984 to 1988 was actually higher than that expected on the basis of previous reports from other Italian cancer registries, ${ }^{20-22}$ and (2) mortality/incidence ratio (one of the most accurate indicators of quality control in cancer registration) was $0 \cdot 7$, a value in keeping with previous observations..$^{2122}$

\section{PUTATIVE HNPCC SYNDROMES}

From our study group we selected 28 families with suspected HNPCC using the following criteria: (1) vertical transmission for at least two generations; (2) presence of two or more family members affected by colorectal cancer besides the proband; (3) early onset of cancer in the proband or in at least one family member; (4) frequent location of cancer in the right colon (caecum, ascending, transverse, and flexures) either in the probands or in their first degree relatives. These criteria closely correspond to those of the International Collaborative Group on HNPCC. ${ }^{23}$

The HNPCC families were analysed separately, since their mode of selection may bias the segregation frequency toward dominance. However, a discontinuity between the HNPCC and other colonic cancers seems to exist, since the proportion we found was the same as that found by other authors.

\section{SUMMARY OF ASCERTAINMENT}

In conclusion, the probability that any patient with colorectal cancer in the province of Modena in 1984 to 1988 escaped inclusion in the sample seems low. Therefore, we believe that our sampling of families was not far from truncate selection, even if a minority $(10.6 \%)$ of the registered patients could not be assessed.

\section{Segregation analysis}

The two sets of data, those concerning the 577 families without evidence of HNPCC and the 28 families with probable HNPCC, were analysed first jointly and then separately, since dominant transmission with high penetrance is well documented for HNPCC. ${ }^{671112}$ Our strategy was as follows. First, we separated the families, irrespective of the type of tumour observed, into three groups: (1) both parents normal, (2) one parent affected, and (3) both affected. When both parents are normal, the hypothesis based on recessivity is that the progeny is the issue of an intercross; when one is affected, the hypothesis is that the progeny issued from a backcross. When both are affected, all the progeny are expected to be affected under recessive transmission and $75 \%$ under dominant transmission, assuming that the frequency of dominant homozygotes is negligible. Therefore, under the recessive model, we classified the families as putative intercrosses (444) and putative backcrosses (144). These have to be analysed separately, since the segregation frequency is expected to be two times larger in backcrosses than in intercrosses. In the small group of 17 families in which both parents were affected, there were 21 of 57 sibs affected with cancer, of whom 18 were affected with colorectal cancer.

For the analysis, we used the following distributions ${ }^{24}$ for the expectation of families of size $s$ with only one affected sib (simplex families) (1) and with more than one affected (multiplex families) (2).

$$
\begin{aligned}
& \mathrm{P}\{\mathrm{r}=1 \mid \mathrm{a}>0 ; \mathrm{s}, \mathrm{p}, \mathrm{x}, \pi\}=\frac{\mathrm{sp} \pi\left\{\mathrm{x}+(1-\mathrm{x})(1-\mathrm{p})^{s-1}\right\}}{\mathrm{xsp} \pi+(1-\mathrm{x})\left\{1-(1-\mathrm{p} \pi)^{s}\right\}} \\
& \mathrm{P}\{\mathrm{r}>1 \mid \mathrm{a}>0 ; \mathrm{s}, \mathrm{p}, \mathrm{x}, \pi\}=\frac{(1-\mathrm{x})(\mathrm{s}) \mathrm{p}^{\mathrm{r}}(1-\mathrm{p})^{s-\mathrm{r}}\left\{1-(1-\pi)^{r}\right\}}{\mathrm{xsp} \pi+(1-\mathrm{x})\left\{1-(1-\mathrm{p} \pi)^{s}\right\}}
\end{aligned}
$$

where $r$ is the number of affected, a the number of probands, $p$ the frequency of segregation, $x$ the frequency of sporadic cases, and $\pi$ the probability of ascertainment.

For the distribution of the number of affected ( $r$ ) in multiplex families of size $s$ we used the following distribution:

$P\{r \mid r>1 ; a>0 ; s, p, \pi\}=\frac{(\stackrel{s}{r}) p^{r}(1-p)^{s-r}\left\{1-(1-\pi)^{r}\right\}}{1-(1-p \pi)^{s}-s p \pi(1-p)^{s-1}}$.

The segregation analysis procedures of estimation of parameters from these distributions are often referred to as Segran 2 and Segran 3.

For each group of families and for each distribution, we estimated the maximum likelihood values of $p, x$, and $\pi$ and obtained the corresponding value of likelihood, which was used as the pivot on which hypotheses were tested, since for each hypothesis a likelihood can be calculated and twice the difference between the maximum likelihood and the 
observed likelihood of the hypothesis is distributed as a $\chi^{2}$, with as many degrees of freedom as the number of parameters kept constant.

\section{Results}

The results of the analysis are given in tables 1 to 5 . For each hypothesis, we report the values of the parameters estimated or kept constant, and the $\chi^{2}$ testing the goodness of fit of the hypothesis (tables $A$ ) and the segregation analysis (tables B).

\section{ONE RECESSIVE GENE, FULLY PENETRANT, NO SPORADIC CASES}

The hypothesis of complete penetrance of a recessive oncogene when homozygous is promptly rejected (tables 1 to 4 , No 1 ). This supports the idea that oncogenes represent a potentiality and do not necessarily result in cancer, as indicated also by the small group of 17 families where both parents are affected.

\section{One recessive gene, fully penetrant, sporadic} cases $>0$

The presence of sporadic cases should occur

Table $1 \mathrm{~A} \quad \chi^{2}$ of transmission hypothesis of carcinomas. Proband affected by colorectal carcinoma. Sibships affected by any type of carcinoma. Probability of ascertainment $(\pi)$ assumed constant per proband.

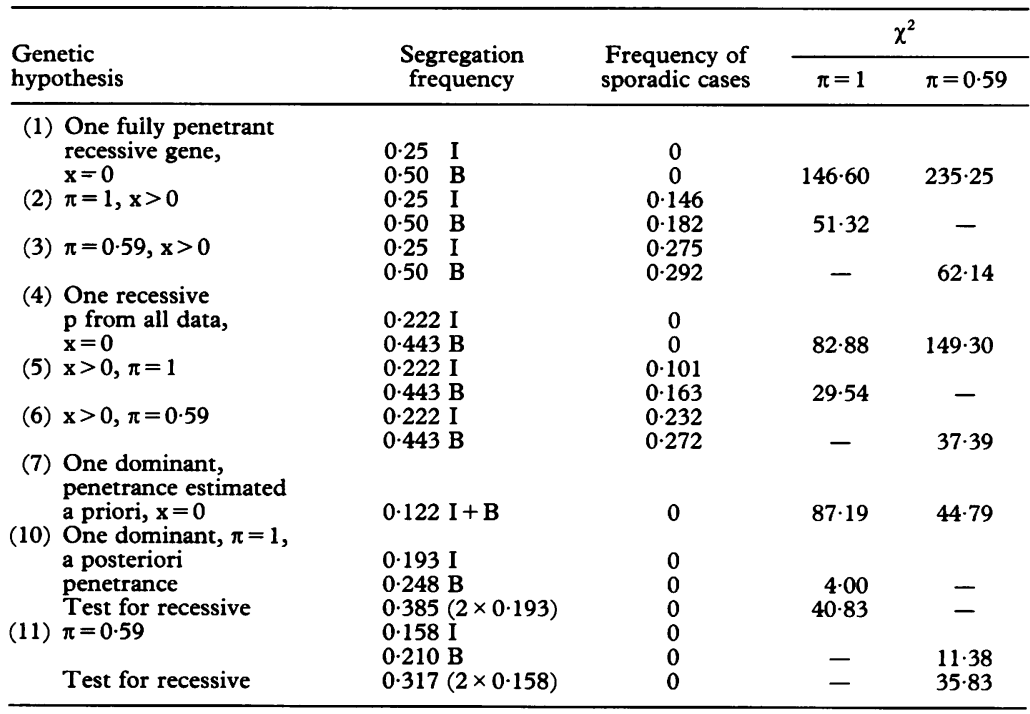

$\mathrm{I}=$ both parents normal, presumed intercross; $\mathrm{B}=$ one parent affected by any carcinoma, presumed backcross. only in families with unaffected parents, since the probability that there is more than one sporadic case in a family is negligible. Then, if sporadic cases are detected also in backcrosses, this demands testing of the alternative hypothesis, namely segregation distortion and corresponding reduced penetrance.

Since in these data the estimation of the frequency of sporadic cases is not compatible with the observed distribution of simplex and multiplex families (tables 1 to 4 , Nos 2 and 3), other hypotheses need to be tested.

One recessive gene, reduced penetrance

The hypothesis of recessivity gains support when the segregation frequency in backcrosses is consistently twice the segregation frequency of intercrosses, also under segregation distortion.

From table 1, Nos 4 to 6 , in which all sibs with all carcinomas are considered, one can see that a recessive gene segregating with the average value of $p$ does not fit the observed distributions either at the observed values of the probability of ascertainment (with a penetrance of $63 \%$ in intercrosses and of $42 \%$ in backcrosses) or under truncate selection (with a penetrance of $77 \%$ in intercrosses and of $50 \%$ in backcrosses).

When one considers only the sibs with colorectal carcinoma (table 2 , Nos 4 to 6 ), the fit is better than in the case of all carcinomas and is acceptable under truncate selection. However, there remains the problem of possible sporadic cases in families with more than one affected; the goodness of fit may be attributed to this additional parameter and the hypothesis would then be rejected. Penetrance would be further reduced, being $27 \%$ for intercrosses and $19 \%$ for presumed backcrosses.

It appears then that we can exclude an important recessive component in these data on colorectal carcinoma after the following observations.

(1) The segregation frequency, which is expected to be double in backcrosses, is not significantly different in presumed backcrosses from presumed intercrosses. (2) The model fits only if there are sporadic cases mixed with familial cases. (3) To accept the model, there should be variable penetrance in intercrosses and backcrosses.

Table $1 B$ Segregation tables.

\begin{tabular}{|c|c|c|c|c|c|c|c|c|c|c|c|c|c|c|c|c|c|c|}
\hline \multicolumn{7}{|c|}{ Both parents normal } & \multicolumn{8}{|c|}{ One parent affected } & \multicolumn{4}{|c|}{ Both parents affected } \\
\hline $\mathbf{s} / \mathbf{r}$ & 1 & 2 & 3 & 4 & 5 & Total & $\mathbf{s} / \mathbf{r}$ & 1 & 2 & 3 & 4 & 5 & 7 & Total & $\mathbf{s} / \mathbf{r}$ & 1 & 2 & Total \\
\hline $\begin{array}{c}1 \\
2 \\
3 \\
4 \\
5 \\
6 \\
7 \\
8 \\
9 \\
10 \\
11 \\
12 \\
14 \\
\text { Total }\end{array}$ & $\begin{array}{r}46 \\
55 \\
53 \\
54 \\
39 \\
26 \\
16 \\
13 \\
8 \\
1 \\
3 \\
- \\
- \\
314\end{array}$ & $\begin{array}{r}11 \\
11 \\
20 \\
14 \\
11 \\
10 \\
6 \\
5 \\
3 \\
1 \\
1 \\
- \\
93\end{array}$ & $\begin{array}{l}3 \\
1 \\
5 \\
- \\
4 \\
4 \\
6 \\
2 \\
- \\
- \\
- \\
25\end{array}$ & $\begin{array}{l}1 \\
\overline{3} \\
\overline{1} \\
1 \\
1 \\
- \\
\overline{1} \\
1\end{array}$ & $\begin{array}{l}-\overline{1} \\
1 \\
\overline{1} \\
1 \\
- \\
- \\
\overline{4}\end{array}$ & $\begin{array}{r}46 \\
66 \\
67 \\
76 \\
58 \\
41 \\
31 \\
24 \\
21 \\
8 \\
4 \\
1 \\
1 \\
444\end{array}$ & $\begin{array}{c}1 \\
2 \\
3 \\
4 \\
5 \\
6 \\
7 \\
8 \\
9 \\
10 \\
11 \\
\text { Total }\end{array}$ & $\begin{array}{r}10 \\
23 \\
16 \\
13 \\
12 \\
7 \\
3 \\
2 \\
2 \\
- \\
1 \\
89\end{array}$ & $\begin{array}{r}3 \\
4 \\
11 \\
6 \\
2 \\
5 \\
3 \\
2 \\
1 \\
1 \\
38\end{array}$ & $\begin{array}{r}1 \\
1 \\
2 \\
2 \\
3 \\
\overline{2} \\
\overline{1} \\
12\end{array}$ & $\begin{array}{l}- \\
\overline{1} \\
1 \\
\overline{1} \\
- \\
\overline{3}\end{array}$ & $\begin{array}{l}\overline{-} \\
\overline{1} \\
- \\
\overline{-} \\
\overline{-} \\
\overline{1}\end{array}$ & $\begin{array}{l}\overline{-} \\
\overline{-} \\
\overline{1} \\
\overline{1} \\
\overline{-} \\
\overline{1}\end{array}$ & $\begin{array}{r}10 \\
26 \\
21 \\
25 \\
20 \\
13 \\
12 \\
6 \\
7 \\
1 \\
3 \\
144\end{array}$ & $\begin{array}{l}1 \\
2 \\
3 \\
4 \\
5 \\
6 \\
\text { Total }\end{array}$ & $\begin{array}{r}\overline{8} \\
\overline{1} \\
4 \\
\overline{1}\end{array}$ & $\begin{array}{l}1 \\
- \\
1 \\
1 \\
1 \\
4\end{array}$ & $\begin{array}{r}\overline{9} \\
\overline{2} \\
5 \\
1 \\
17\end{array}$ \\
\hline
\end{tabular}


ONE DOMINANT GENE

Complete penetrance

We have 144 families with one affected parent and 444 families with both parents unaffected. Complete penetrance is thus ruled out for the dominant transmission model. A priori penetrance under the backcross hypothesis is obtained from the ratio of families with one parent affected over all families; it is assumed that all families belong to the type of cross $\mathrm{Aa} \times \mathrm{aa}$, where Aa is affected and aa normal. When both parents were normal, the allele was non-penetrant. A priori penetrance then is $y=144 / 588=0 \cdot 245$.

\section{Reduced penetrance}

From a priori penetrance, the segregation frequency can be estimated to be $0 \cdot 1224$ (tables 1 and 2, No 7); however, the hypothesis does not fit either under truncate selection or at $\pi=0.59$ $\left(\chi^{2}=44 \cdot 79,1 \mathrm{df}\right.$ for sibships affected by any type of carcinoma; $\chi^{2}=69 \cdot 46$ for sibships affected by colorectal carcinoma only). From these 588 families, the hypothesis of dominance can be rejected at penetrance as high as $25 \%$. Before reconsidering a further decrease

Table $2 A \quad \chi^{2}$ of transmission hypothesis of carcinomas. Proband affected by colorectal carcinoma. Sibships affected by only colorectal carcinoma. Probability of ascertainment $(\pi)$ assumed constant per proband.

\begin{tabular}{|c|c|c|c|c|c|}
\hline \multirow{2}{*}{\multicolumn{2}{|c|}{$\begin{array}{l}\text { Genetic } \\
\text { hypothesis }\end{array}$}} & \multirow[b]{2}{*}{$\begin{array}{l}\text { Segregation } \\
\text { frequency }\end{array}$} & \multirow{2}{*}{$\begin{array}{l}\text { Frequency of } \\
\text { sporadic cases }\end{array}$} & \multicolumn{2}{|c|}{$\chi^{2}$} \\
\hline & & & & $\pi=1$ & $\pi=0.67$ \\
\hline \multicolumn{6}{|c|}{ (1) One fully penetrant } \\
\hline & recessive gene, & $0 \cdot 25 \quad I$ & 0 & & \\
\hline & $x=0$ & $\begin{array}{ll}0.50 & \mathrm{~B} \\
0.25 & \mathrm{I}\end{array}$ & $\begin{array}{c}0 \\
0.587\end{array}$ & $521 \cdot 97$ & $664 \cdot 20$ \\
\hline (2) $\mathrm{x}$ & $x>0, \pi=1$ & $\begin{array}{ll}0.25 & \text { I } \\
0.50 & \mathrm{~B}\end{array}$ & 0.561 & $65 \cdot 72$ & - \\
\hline \multirow[t]{2}{*}{ (3) } & $x>0, \pi=0.67$ & 0.25 I & 0.675 & & \\
\hline & & $0.50 \quad \mathrm{~B}$ & 0.650 & - & $70 \cdot 15$ \\
\hline \multirow{2}{*}{ (4) } & $\begin{array}{l}\text { One recessive } \\
\text { p from all data, }\end{array}$ & $0.086 \mathrm{I}$ & 0 & & \\
\hline & $x=0$ & $0.172 \mathrm{~B}$ & 0 & $20 \cdot 75$ & $49 \cdot 14$ \\
\hline & $x>0, \pi=1$ & $\begin{array}{l}0.086 \mathrm{I} \\
0.172 \mathrm{~B}\end{array}$ & $\begin{array}{l}0.208 \\
0.343\end{array}$ & $1 \cdot 40$ & - \\
\hline$(6)$ & $x>0, \pi=0.67$ & $\begin{array}{l}0.086 \mathrm{I} \\
0.172 \mathrm{~B}\end{array}$ & $\begin{array}{l}0.364 \\
0.466\end{array}$ & - & $2 \cdot 42$ \\
\hline \multirow{4}{*}{$\begin{array}{l}(7) \\
(8) \\
(9) \\
(10)\end{array}$} & \multirow{3}{*}{$\begin{array}{l}\text { One dominant, } \\
\text { a priori penetrance } x=0 \\
x>0, \pi=1 \\
x>0, \pi=0.67 \\
\text { One dominant. }\end{array}$} & $0 \cdot 122 I+B$ & 0 & $31 \cdot 38$ & $69 \cdot 46$ \\
\hline & & $0 \cdot 122 I+B$ & 0.333 & 0.49 & - \\
\hline & & $0 \cdot 122 \mathrm{I}+\mathrm{B}$ & $0 \cdot 464$ & - & $2 \cdot 00$ \\
\hline & $\pi=1$, a posteriori & $0.068 \mathrm{I}$ & 0 & & \\
\hline & penetrance & $0.097 \mathrm{~B}$ & 0 & $1 \cdot 71$ & - \\
\hline & Test for recessive & $0.136(2 \times 0.068)$ & 0 & $6 \cdot 06$ & 一 \\
\hline \multirow[t]{2}{*}{ (11) } & $\pi=0.67$ & 0.054 I & $\begin{array}{l}0 \\
0\end{array}$ & & \\
\hline & Test for recessive & $\begin{array}{l}0.078 \mathrm{~B} \\
0.107(2 \times 0.054)\end{array}$ & $\begin{array}{l}0 \\
0\end{array}$ & $\overline{-}$ & $\begin{array}{l}7.87 \\
7.35\end{array}$ \\
\hline
\end{tabular}

$\mathrm{I}=$ both parents normal, presumed intercross; $\mathrm{B}=$ one parent affected by any carcinoma, presumed backcross. of the segregation frequency under the dominant transmission hypothesis, we tested segregation after exclusion of suspected HNPCC syndromes.

\section{EXCLUSION OF SUSPECTED HNPCC}

Suspected HNPCC syndromes might affect the segregation frequency, so the data were examined after their exclusion (tables 3 and 4 ). There are 436 families with no affected parents and 130 families with one affected parent after exclusion. A priori penetrance is $23 \%$ under dominant transmission, only slightly changed from all cancers. The recessive hypotheses do not fit (tables 3 and 4 , Nos 1 to 6). Also dominant transmission does not fit at the segregation frequency estimated from a priori penetrance either under truncate or multiple selection; the $\chi^{2}$ are very high (tables 3 and 4, No 7).

\section{DOMINANT TRANSMISSION, ESTIMATED}

\section{PENETRANCE}

The indication of sporadic cases when one parent is affected (table 4, Nos 8 and 9) is against the genetic hypothesis. The equality of the segregation frequency in families where one parent is affected and in families where no parent is affected negates the presence of a significant fraction of sporadic cases (tables 3 and 4, Nos 7 to 9 , note also that the estimated value of $\mathrm{x}$ is larger in backcrosses). The estimated segregation frequency when both parents are normal should be smaller in the presence of sporadic cases since these increase the proportion of simplex families. Therefore, with these data, under the genetic hypothesis the segregation of colorectal carcinoma in families seems mainly conditioned by reduced penetrance.

The result of equal segregation frequency in both mating types makes recessive transmission highly questionable, and the model which emerges more or less intact from the analysis is that the major gene segregating in families with colorectal carcinoma is a dominant with greatly reduced penetrance (table 4 , Nos 10 and 11). The estimation of $p$ from all families (suspected HNPCC syndromes excluded), considering only sibs with colorectal carcinoma, gives $p=0.066 \pm 0.008$ (table 4 , No 10) under truncate selection and $p=0.052 \pm 0.007$ at $\pi=0.67$ (table 4 , No 11 ). The second value is then the one which, with these data and in this population, estimates the risk of recurrence

Table $2 B$ Segregation tables.

\begin{tabular}{|c|c|c|c|c|c|c|c|c|c|c|c|c|c|c|}
\hline \multicolumn{6}{|c|}{ Both parents normal } & \multicolumn{5}{|c|}{ One parent affected } & \multicolumn{4}{|c|}{ Both parents affected } \\
\hline $\mathbf{s} / \mathbf{r}$ & 1 & 2 & 3 & 4 & Total & $\mathbf{s} / \mathbf{r}$ & 1 & 2 & 7 & Total & $\mathbf{s} / \mathbf{r}$ & 1 & 2 & Total \\
\hline $\begin{array}{c}1 \\
2 \\
3 \\
4 \\
5 \\
6 \\
7 \\
8 \\
9 \\
10 \\
11 \\
12 \\
14 \\
\text { Total }\end{array}$ & $\begin{array}{r}46 \\
63 \\
64 \\
68 \\
51 \\
35 \\
24 \\
20 \\
14 \\
6 \\
4 \\
1 \\
- \\
396\end{array}$ & $\begin{array}{r}3 \\
3 \\
8 \\
7 \\
2 \\
6 \\
4 \\
5 \\
2 \\
- \\
- \\
1 \\
41\end{array}$ & $\begin{array}{l}- \\
- \\
\overline{3} \\
1 \\
\overline{2} \\
- \\
- \\
- \\
\overline{6}\end{array}$ & $\begin{array}{l}- \\
\overline{1} \\
- \\
- \\
\overline{-} \\
\overline{-} \\
- \\
\overline{1} \\
\overline{1}\end{array}$ & $\begin{array}{r}46 \\
66 \\
67 \\
76 \\
58 \\
41 \\
31 \\
24 \\
21 \\
8 \\
4 \\
1 \\
1 \\
444\end{array}$ & $\begin{array}{c}1 \\
2 \\
3 \\
4 \\
5 \\
6 \\
7 \\
8 \\
9 \\
10 \\
11 \\
\text { Total }\end{array}$ & $\begin{array}{r}10 \\
24 \\
18 \\
22 \\
19 \\
11 \\
8 \\
4 \\
4 \\
1 \\
1 \\
122\end{array}$ & $\begin{array}{r}2 \\
3 \\
3 \\
1 \\
2 \\
4 \\
1 \\
3 \\
- \\
2 \\
21\end{array}$ & $\begin{array}{l}1 \\
- \\
- \\
\overline{1}\end{array}$ & $\begin{array}{r}10 \\
26 \\
21 \\
25 \\
20 \\
13 \\
12 \\
6 \\
7 \\
1 \\
3 \\
144\end{array}$ & $\begin{array}{l}1 \\
2 \\
3 \\
4 \\
5 \\
6 \\
\text { Total }\end{array}$ & $\begin{array}{r}\overline{9} \\
\overline{2} \\
4 \\
1 \\
16\end{array}$ & $\begin{array}{l}- \\
- \\
\overline{1} \\
\overline{1}\end{array}$ & $\begin{array}{r}\overline{9} \\
\overline{2} \\
5 \\
1 \\
17\end{array}$ \\
\hline
\end{tabular}


better. From this result, penetrance of the dominant gene is only $10.4 \%$, implying the presence of a large number of factors which can modify the expression of the major gene in the heterozygous state. The analysis of the 17 families with sibs affected by only colorectal carcinoma and with both parents affected (dominant intercrosses under the model) showed that the segregation frequency is compatible with the expected value of $0.75 \mathrm{y}=0.75 \times 0.104=0.078$ $\left(\chi^{2}=0.815\right.$ at $\left.\pi=0.67\right)$. However, the small number of families results in a large standard error for $\mathrm{p}$, and the evidence, although indicative, is not confirmatory.

\section{TESTING THE MULTIFACTORIAL MODEL}

The reduced penetrance might result from any number of factors which could affect the expression of the major gene. Therefore, it seems appropriate to test for the multifactorial model as well.

According to Edwards, ${ }^{25}$ the expected segregation frequency for polygenic traits is the square root of the population incidence. The incidence of cancer of any type is strongly dependent on age, so the cumulative incidence is likely to increase with age. However, at any

Table $3 \mathrm{~A} \quad \chi^{2}$ of transmission hypothesis of carcinomas. Proband affected by colorectal carcinoma. Sibships affected by any type of carcinoma. Suspected HNPCC syndromes excluded. Probability of ascertainment $(\pi)$ assumed constant per proband.

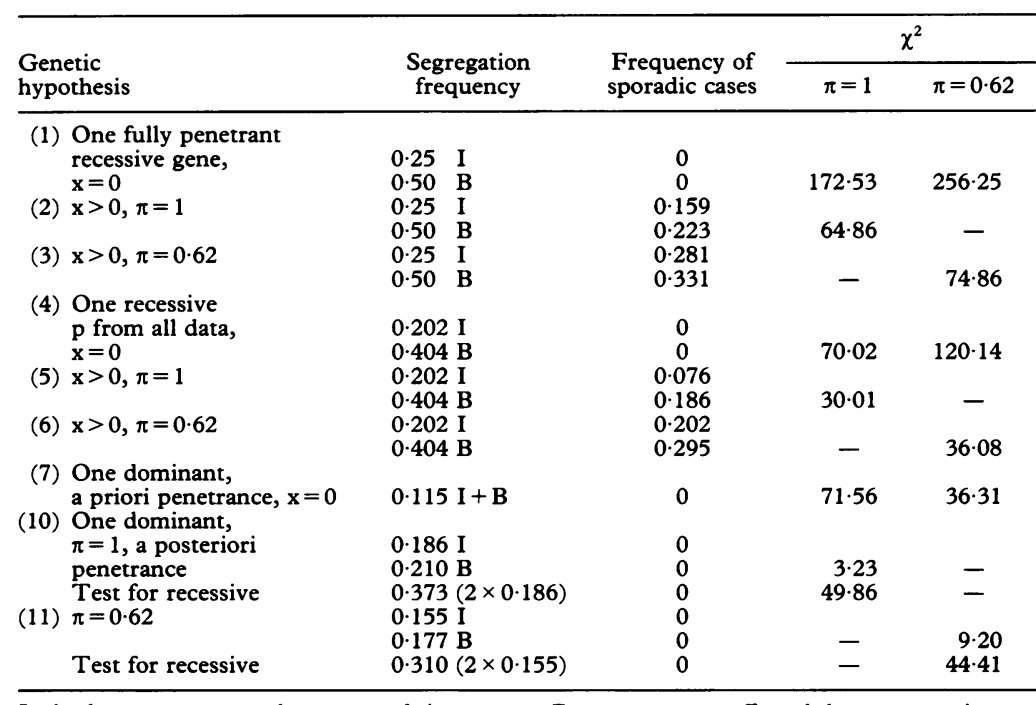

$\mathrm{I}=$ both parents normal, presumed intercross; $\mathrm{B}=$ one parent affected by any carcinoma presumed backcross. time under stability of gene frequencies, of the age distribution, and of the environment, the number of cases alive should also stay constant in a population.

In Modena, the average number of cases alive at any time during this investigation was 285 out of 263500 inhabitants. The prevalence is then 0.001084 , one case per 1000 inhabitants. If we use the square root of this figure for the estimation of segregation frequency under the multifactorial model, we obtain $p=0.033$, which is smaller but not significantly so than the estimate obtained by the monogenic model.

On the other hand, if we were to use the cumulative lifetime incidence, say 0.06 to $0.08,1821$ then the expected segregation frequency under the multifactorial model would be significantly higher than the observed one.

In the present data, however, we have no obvious evidence that the risk to unaffected sibs increases with the number of affected in the sibship, as is expected under multifactorial transmission. Furthermore, the segregation frequency is not greater when one parent is affected as is expected under the multifactorial model. After these considerations, although we cannot exclude polygenic inheritance underlying the observed segregation, we consider the evidence for multifactorial transmission unsatisfactory.

TENTATIVE ESTIMATE OF GENE FREQUENCY

With dominant inheritance it is possible to estimate the gene frequency. The expressed gene frequency is half of the disease frequency, namely 0.000542 , but this has to be corrected by the inverse of the penetrance; then, the frequency of the gene is estimated to be 0.0052 . Since the gene is expressed in approximately one-tenth of the cases, and usually a long time after reproduction, the maintenance of such a high frequency does not fit in a simple way with either mutational or segregational equilibria.

\section{SUSPECTED HNPCC SYNDROMES}

In table 5 ( $A$ and $B$ ), we show the analysis of the 28 families which were classified as suspected HNPCC syndromes. In this case, one cannot separate the families into backcrosses and intercrosses, since all are putative backcrosses. When both parents have a normal

Table $3 B$ Segregation tables.

\begin{tabular}{|c|c|c|c|c|c|c|c|c|c|c|c|c|c|}
\hline \multicolumn{7}{|c|}{ Both parents normal } & \multicolumn{7}{|c|}{ One parent affected } \\
\hline $\mathbf{s} / \mathbf{r}$ & 1 & 2 & 3 & 4 & 5 & Total & $\mathbf{s} / \mathbf{r}$ & 1 & 2 & 3 & 4 & 5 & Total \\
\hline 1 & 45 & & & & & 45 & 1 & 10 & & & & & 10 \\
\hline 2 & 55 & 10 & & & & 65 & 2 & 19 & 2 & & & & 21 \\
\hline 3 & 53 & 9 & 2 & & & 64 & 3 & 16 & 3 & - & & & 19 \\
\hline 4 & 54 & 18 & 1 & 1 & & 74 & 4 & 13 & 10 & 1 & - & & 24 \\
\hline 5 & 39 & 14 & 4 & - & - & 57 & 5 & 12 & 6 & 2 & - & - & 20 \\
\hline 6 & 26 & 11 & - & 3 & 1 & 41 & 6 & 7 & 2 & - & - & 1 & 10 \\
\hline 7 & 16 & 10 & 4 & - & 1 & 31 & 7 & 3 & 4 & 2 & 1 & - & 10 \\
\hline 8 & 13 & 6 & 4 & 1 & - & 24 & 8 & 2 & 3 & - & - & - & 5 \\
\hline 9 & 8 & 5 & 6 & 1 & 1 & 21 & 9 & 2 & 2 & 2 & 1 & - & 7 \\
\hline 10 & 1 & 3 & 2 & 1 & 1 & 8 & 10 & - & 1 & - & - & - & $i$ \\
\hline 11 & 3 & 1 & - & - & - & 4 & 11 & 1 & 1 & 1 & - & - & 3 \\
\hline 12 & - & 1 & - & - & - & 1 & Total & 85 & 34 & 8 & 2 & 1 & 130 \\
\hline 14 & - & - & - & 1 & - & 1 & & & & & & & \\
\hline Total & 313 & 88 & 23 & 8 & 4 & 436 & & & & & & & \\
\hline
\end{tabular}


Table 4A $\chi^{2}$ of transmission hypothesis of carcinomas. Proband affected by colorectal carcinoma. Sibships affected by colorectal carcinoma only. Suspected HNPCC syndromes excluded. Probability of ascertainment $(\pi)$ assumed constant per proband.

\begin{tabular}{|c|c|c|c|c|c|}
\hline \multirow{2}{*}{\multicolumn{2}{|c|}{$\begin{array}{l}\text { Genetic } \\
\text { hypothesis }\end{array}$}} & \multirow{2}{*}{$\begin{array}{c}\text { Segregation } \\
\text { frequency }\end{array}$} & \multirow{2}{*}{$\begin{array}{l}\text { Frequency of } \\
\text { sporadic cases }\end{array}$} & \multicolumn{2}{|c|}{$\chi^{2}$} \\
\hline & & & & $\pi=1$ & $\pi=0.67$ \\
\hline \multicolumn{6}{|c|}{ (1) One fully penetrant } \\
\hline & $x=0$ & $0.50 \mathrm{~B}$ & 0 & $539 \cdot 16$ & $679 \cdot 13$ \\
\hline (2) $\pi$ & $\pi=1, x>0$ & $0.25 \quad \mathrm{I}$ & 0.596 & & \\
\hline & & $0.50 \mathrm{~B}$ & 0.631 & 76.01 & - \\
\hline (3) $\pi$ & $\pi=0.67, x>0$ & $0.25 \quad I$ & $0 \cdot 683$ & & \\
\hline \multirow{2}{*}{ (4) } & One recessive & 0.50 B & 0.712 & - & $79 \cdot 81$ \\
\hline & $\begin{array}{l}\mathrm{p} \text { from all data, } \\
\mathrm{x}=0\end{array}$ & $\begin{array}{l}0.068 \mathrm{I} \\
0.137 \mathrm{~B}\end{array}$ & $\begin{array}{l}0 \\
0\end{array}$ & $16 \cdot 59$ & 33.46 \\
\hline & $x>0, \pi=1$ & $0.068 \mathrm{I}$ & 0.072 & & \\
\hline & $x>0, \pi=0.67$ & $\begin{array}{l}0 \cdot 137 \mathrm{~B} \\
0.086 \mathrm{I}\end{array}$ & $\begin{array}{l}0.361 \\
0 \cdot 255\end{array}$ & $7 \cdot 00$ & - \\
\hline (6) & & $0 \cdot 172 \mathrm{~B}$ & 0.490 & - & $7 \cdot 57$ \\
\hline & $\begin{array}{l}\text { One dominant, } \\
\text { penetrance estimated }\end{array}$ & & & & \\
\hline & a priori, $x=0$ & $\begin{array}{l}0 \cdot 115 \mathrm{I}+\mathrm{B} \\
0 \cdot 115 \mathrm{I}+\mathrm{B}\end{array}$ & $\begin{array}{c}0 \\
0.350\end{array}$ & $\begin{array}{r}33 \cdot 36 \\
3.86\end{array}$ & $69 \cdot 32$ \\
\hline (9) $x$ & $x>0, \pi=0.67$ & $0.115 \mathrm{I}+\mathrm{B}$ & 0.482 & - & 5.00 \\
\hline \multirow{3}{*}{ (10) } & $\pi=1$, a posteriori & $0.066 \mathrm{I}$ & 0 & & \\
\hline & penetrance & $0.066 \mathrm{~B}$ & 0 & $2 \cdot 32$ & - \\
\hline & $\begin{array}{l}\text { Test for recessive } \\
\pi=0.67\end{array}$ & $\begin{array}{l}0.132(2 \times 0.066) \\
0.052 I\end{array}$ & $\begin{array}{l}0 \\
0\end{array}$ & 15.06 & - \\
\hline \multirow{2}{*}{ (11) } & & $0.052 \mathrm{~B}$ & 0 & - & $3 \cdot 26$ \\
\hline & Test for recessive & $0.104(2 \times 0.052)$ & 0 & - & $14 \cdot 85$ \\
\hline
\end{tabular}

$\mathrm{I}=$ both parents normal, presumed intercross; $\mathrm{B}=$ one parent affected by any carcinoma, presumed backcrosses. estimation of the segregation frequency at $\pi>0.81$ and $\mathrm{p}=0.267$, and under truncate selection $p=0 \cdot 286$. After estimation of $p$, the a posteriori penetrance is $57 \%$, less than the a priori penetrance estimated from the number of affected parents.

\section{Discussion}

The first report on the relevance of genetic factors in colorectal cancer dates back to 1913, when Warthin ${ }^{26}$ described the first Cancer Family Syndrome. Subsequently, efforts of other authors contributed to the definition of hereditary colorectal cancer. ${ }^{6712}$ More recently, several lines of evidence suggest that HNPCC syndromes account for approximately $5 \%$ of all cancers of the large bowel. ${ }^{12} 1727$ In parallel with these studies, other investigators reported the frequent familial aggregation of colorectal cancer, though a clear mendelian pattern of transmission was not present. ${ }^{8916}$ The commonly accepted interpretation of the frequent occurrence of colorectal neoplasms among first degree relatives of affected subjects has been polygenic inheritance. ${ }^{11}$ Recently, however, Burt et $a l^{13}$ and Cannon-Albright et $a l^{14}$ presented evidence of dominant inheritance of apparently sporadic colorectal cancers and polyps. The study was carried out through the systematic screening for colorectal neoplasms using flexible sigmoidoscopy. Their findings, initially limited to a single large kindred, were subsequently extended to 34 kindreds, with virtually the same results. The importance of these observations lies in the fact that for the first time a mendelian basis was suggested to explain the susceptibility to the commonly observed colorectal cancer. There are, however, two main drawbacks in these investigations. First, in the evaluation of their results the authors gave the same relevance to the observed cancers and to adenomatous polyps. Although this might appear logical, especially if one considers the sequence adenoma-carcinoma, it is also true that only a small minority of polyps undergo malignant transformation, while the large majority remain benign or disappear. Indeed, the frequency of polyps in the general population has been estimated to be of the order of $30 \%,{ }^{2829}$ whereas the cumulative risk ( 0 to 75 years) of colorectal cancer is approximately 6 to $8 \%^{1821}$; this means that presumably fewer than $10 \%$ of polyps degenerate into cancer. Thus, although the pathogenesis is probably similar and adenomas represent the natural precursor of many malignant tumours, polyps and cancer represent two different nosological entities and they should receive a different weight in the analysis of the results. The second drawback of the study is the selection of cases; although the authors studied 34 large kindreds with a total of 670 subjects, these families were somehow selected and consequently not entirely representative of the clinically observed colorectal cancers. Their findings, therefore, can be extrapolated to the general population only with caution.

In the present investigation, we used a values of the probability of ascertainment, does not fit the families classified as putative HNPCC when the colorectal cancers alone are taken into account in the sibships $\left(\chi^{2}=21.66\right.$, $1 \mathrm{df}, \mathrm{p}<0.01)$. The fit is good, however, after 
Table $5 A \quad \chi^{2}$ of transmission hypothesis of suspected HNPCC syndromes. Sibships affected by any type of carcinoma. Probability of ascertainment assumed constant per proband.

\begin{tabular}{lcccc}
\hline & $\begin{array}{c}\text { Segregation } \\
\text { frequency }\end{array}$ & $\begin{array}{c}\text { Sporadic } \\
\text { cases }\end{array}$ & & \multicolumn{2}{c}{$\chi^{2}$} \\
\cline { 4 - 5 } & 0.5 & 0 & 0.293 & 0.072 \\
\hline $\begin{array}{l}\text { (1) One mendelian dominant } \\
\text { gene }\end{array}$ & 0.5536 & 0 & 0.432 & 1.264 \\
$\begin{array}{l}\text { (2) One fully penetrant } \\
\text { dominant gene }\end{array}$ & 0.5231 & 0 & 0.112 & - \\
$\begin{array}{l}\text { (3) One dominant gene with } \\
\text { reduced penetrance }\end{array}$ & 0.4927 & 0 & - & 0.055 \\
\hline
\end{tabular}

When all sibs affected by any carcinoma are taken into account, in the sibships classified as suspected HNPCC syndromes the hypothesis of a dominant gene is not rejected.

Table 5B $\chi^{2}$ for transmission hypothesis of suspected HNPCC syndromes. Only sibs with colorectal carcinoma considered. Probability of ascertainment assumed constant per proband.

\begin{tabular}{|c|c|c|c|c|c|}
\hline & & \multirow{2}{*}{$\begin{array}{l}\text { Segregation } \\
\text { frequency }\end{array}$} & \multirow{2}{*}{$\begin{array}{c}\text { Sporadic } \\
\text { cases }\end{array}$} & \multicolumn{2}{|c|}{$\chi^{2}$} \\
\hline & & & & $\pi=1$ & $\pi=0.8136$ \\
\hline \multirow{4}{*}{\multicolumn{2}{|c|}{$\begin{array}{l}\text { (1) One mendelian dominant } \\
\text { gene } \\
\text { (2) One fully penetrant } \\
\text { dominant gene } \\
\text { (3) One dominant gene with } \\
\text { reduced penetrance } \\
\text { Penetrance }\end{array}$}} & 0.5 & 0 & $13 \cdot 771$ & $17 \cdot 010$ \\
\hline & & 0.5536 & 0 & 21.659 & $25 \cdot 416$ \\
\hline & & $0 \cdot 2862$ & 0 & $0 \cdot 150$ & - \\
\hline & & $0 \cdot 2666$ & 0 & - & 0.829 \\
\hline
\end{tabular}

A dominant gene with penetrance reduced to about $50 \%$ would account for the distribution of the affected with colorectal carcinoma in families with suspected HNPCC syndromes.

\begin{tabular}{|c|c|c|c|c|c|c|c|c|c|c|c|c|}
\hline \multicolumn{13}{|c|}{ Putative HNPCC syndromes } \\
\hline \multicolumn{7}{|c|}{ All cancers } & \multicolumn{6}{|c|}{ Only colorectal cancer } \\
\hline $\mathbf{s} / \mathbf{r}$ & 1 & 2 & 3 & 4 & 7 & Total & $\mathbf{s} / \mathbf{r}$ & 1 & 2 & 3 & 7 & Total \\
\hline 1 & 1 & & & & & 1 & 1 & 1 & & & & 1 \\
\hline 2 & 7 & 2 & & & & 9 & 2 & 9 & - & & & 9 \\
\hline 3 & 1 & 3 & 2 & & & 6 & 3 & 4 & 2 & - & & 6 \\
\hline 4 & - & 3 & - & - & & 3 & 4 & 2 & 1 & - & & 3 \\
\hline 5 & - & - & 1 & - & & 1 & 5 & - & 1 & - & & 1 \\
\hline 6 & 1 & - & 2 & 1 & & 4 & 6 & 2 & 2 & - & & 4 \\
\hline 7 & - & 1 & 1 & 1 & - & 3 & 7 & 1 & 1 & 1 & - & 3 \\
\hline 8 & - & - & - & - & 1 & 1 & 8 & - & 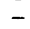 & - & 1 & 1 \\
\hline Total & 10 & 9 & 6 & 2 & 1 & 28 & Total & 19 & 7 & 1 & 1 & 28 \\
\hline
\end{tabular}

population sample and reached similar conclusions. It should be noted that our data derive from a population based Registry and that only the endpoint 'cancer' (directly diagnosed, verified or deduced by history) entered the segregation analysis. We agree with Burt et al $^{13}$ and Cannon-Albright et $a{ }^{14}{ }^{14}$ who suggested that susceptibility to colorectal cancer in the majority of affected subjects may be the result of a dominant gene with reduced penetrance. Thus, through classical segregation analysis carried out on data from a population based Registry, we obtained indications that colorectal carcinoma may be attributed to at least two genetically heterogeneous entities: inheritance is compatible with an autosomal dominant type of transmission, with high penetrance in a small proportion $(28 / 605=4 \cdot 6 \%)$, whereas a larger proportion $(577 / 605=95 \cdot 4 \%)$ show features of dominant transmission with greatly reduced penetrance.

It may be questioned whether segregation distortion owing to reduced penetrance might be simulated by sporadic cases; however, in this sample a high frequency of sporadic cases under the genetic hypothesis was not found. Two considerations emerge. The first and strongest consideration is that the frequency of segregation is the same when one or no parent is affected. The second is that the frequency of sporadic cases, when estimated under the dominant model, should be the same in the families we classified as presumed intercrosses as in the presumed backcrosses; this was not observed. Thus, we agree with others that susceptibility to colorectal carcinoma, in the majority of cases, is transmitted by one dominant gene with reduced penetrance, which may be as low as $10 \%$.

From the practical point of view, the recurrence risk to sibs is in the order of $5 \%$ if both parents are normal, and does not increase significantly when one parent is affected. One should be cautious, however, when interpreting these results. Although 'classical' HNPCC can be easily recognised and analysed separately, it is possible that other cases of this syndrome escape detection, especially because of the small size of several families and the variable expression of the features associated with the syndrome. We cannot exclude, therefore, that the estimated segregation frequency in tables 3 and 4 might be somewhat inflated by the presence of undetected HNPCC families.

The possible genetic basis of virtually all cases of colorectal cancer does not exclude the role of environmental factors in the pathogenesis of the disease. Thus, there is no doubt that factors like diet, Western style of life, job activity, inflammatory bowel diseases, and many other conditions are epidemiologically related to colorectal cancer. ${ }^{1-330}$ Because of the complex interaction between environmental and genetic factors, ${ }^{31}$ we can assume that the genetic background determines which subjects in the general population are prone to develop colorectal cancer; subsequently, over the course of many years, epigenetic (mostly environmental) factors may interact with genes in susceptible persons determining the fraction who will become affected.

The histogenesis of colorectal cancer has often been interpreted as a multistep sequence. According to this hypothesis the first abnormality seems to be a hyperproliferative state of the colorectal mucosa, characterised by an expansion of the cytoproliferative zone from the lower to the upper portions of the intestinal crypts. ${ }^{32-34}$ Further events are the budding of small adenomas and their subsequent growth to large polyps; eventually, part of these adenomas degenerate into malignant tumours. ${ }^{35}$

Recently it has been suggested that the various steps of colorectal tumour formation might be the consequence of the accumulation of genetic changes involving both oncogenes and tumour suppressor genes. ${ }^{36}$ Point mutations of K-ras, hypomethylation of DNA, and allelic losses in chromosome 5 appear to be early events associated with the induction of cell hyperproliferation and the appearance of small (less than $10 \mathrm{~mm}$ ) adenomas. On the other hand, deletions of chromosomes 17 or 18 or of other chromosomes seem to represent late events mainly involved in the progression of large adenomas to infiltrating carcinomas. ${ }^{37-39}$ This sequence of events at the somatic cell level, in particular deletion of suppressors, is 
not in conflict with a dominant genetic basis for the resulting neoplasms.

Our data indicate the presence of a major gene for susceptibility. We realise, however, that our ignorance of the residual set of factors influencing its expression is measured by the level of non-penetrance, namely $89 \cdot 6 \%$.

Further studies are needed to extend our observations, to investigate any other possible modes of inheritance, and to explore in more detail the complex interaction between environment and genetics in the pathogenesis of colorectal cancer.

This work was conducted in part with the financial assistance of the Italian Ministry of the Universities and of Scientific and Technological Research (MURST) and with a grant from the Regione Emilia-Romagna (15/3/86, 1970). Drs G Zanghieri and C Sacchetti were supported in part by the Lega Italiana per la Lotta contro i Tumori, Sezione di Modena. Dr $R$ Sassatelli was supported by the Associazione Italiana per la Ricerca sul Cancro (AIRC). The authors wish to dedicate this work to the VIth Centennial Jubilaeum of the University of Ferrara, 1391-1991.

1 Graham S, Dayal H, Swanson M, Mittelman A, Wilkinson $G$. Diet in the epidemiology of cancer of the colon and G. Diet in the epidemiology of cancer of the
rectum. $f$ Natl Cancer Inst 1978;61:709-14.

2 Graham S, Marshall J, Haughey B, et al. Dietary epidemiology of cancer of the colon in western New York. Am $\mathcal{F}$ Epidemiol 1988;128:490-503.

3 Vena JE, Graham S, Zielezny M, Swanson MK, Barnes RE, Nolan J. Lifetime occupational exercise and colon cancer. Am $\mathcal{f}$ Epidemiol 1984;119:1005-14.

4 Naylor EW, Lebenthal E. Gardner's syndrome: recent developments in research and management. Dig Dis $\mathrm{Sc}$ 1980;25:945-59.

5 Lipkin M, Winawer SJ, Sherlock P. Early identification of individuals at increased risk for cancer of the large intestine. Part I: definition of high risk populations. Clin Bull 1981;11:13-21.

6 Lynch HT, Watson P, Kriegler M, et al. Differential diagnosis of hereditary nonpolyposis colorectal cancer diagnosis of hereditary nonpolyposis colorectal cancer
(Lynch syndrome I and Lynch syndrome II). Dis Colon Rectum 1988;31:372-7.

7 Lynch HT, Watson P, Lanspa SJ, et al. Natural history of colorectal cancer in hereditary nonpolyposis colorectal cancer (Lynch syndromes I and II). Dis Colon Rectum 1988;31:439-44.

8 Lovett E. Family studies in cancer of the colon and rectum. $\operatorname{Br} \mathcal{F}$ Surg 1976;63:13-18.

9 Rozen P, Fireman Z, Figer A, Legum C, Ron E, Lynch HT. Family history of colorectal cancer as a marker of potential malignancy within a screening program. Cancer 1987;60:248-54

10 Rozen P, Lynch HT, Figer A, et al. Familial colon cancer in the Tel-Aviv area and influence of ethnic origin. Cancer 1987;60:2355-9.

11 Lynch HT, Kimberling W, Albano WA, et al. Hereditary nonpolyposis colorectal cancer (Lynch syndromes I and
II). I. Clinical description of resource. Cancer 1985;56:934-8.

12 Fitzgibbons RJ Jr, Lynch HT, Stanislav GV, et al. Recognition and treatment of patients with hereditary nonpolyposis colon cancer (Lynch syndromes I and II). Ann Surg 1987;206:289-94.

13 Burt RW, Bishop T, Cannon LA, Dowdle MA, Lee RG, Skolnick MH. Dominant inheritance of adenomatous colonic polyps and colorectal cancer. $N$ Engl $\mathcal{F} \mathrm{Med}$ 1985;312:1540-4.
14 Cannon-Albright LA, Skolnick MH, Bishop T, Lee RG, Burt RW. Common inheritance of susceptibility to colonic adenomatous polyps and associated colorectal cancers. N Engl f Med 1988;319:533-7.

15 Veale AMO. Investigation of a genetic model. In: Lynch HT, Lynch JF, eds. Colon cancer genetics. New York: Van Nostrand Reinhold, 1985:17-29.

16 Ponz de Leon M, Antonioli A, Ascari A, Zanghieri G, Sacchetti C. Incidence and familial occurrence of colorectal cancer and polyps in a health-care district of Northern tal cancer and polyps in a health-ca

17 Ponz de Leon M, Sassatelli R, Sacchetti C, Zanghieri G, Scalmati A, Roncucci L. Familial aggregation of tumors in the 3-year experience of a population-based colorectal cancer registry. Cancer Res 1989;49:4344-8.

18 Ponz de Leon M, Sacchetti C, Zanghieri G, Antonioli A. Epidemiology of tumors of the digestive organs: incidence, mortality and familiality in the health care district of Modena 1984-1986. Boll Ord Medici della Prov di Modena 1987; suppl 9:1-79.

19 Sellers TA, Ooi WL, Elston RC, Chen VW, Bailey-Wilson $\mathrm{JE}$, Rothschild $\mathrm{H}$. Increased familial risk for non-lung cancer among relatives of lung cancer patients. $\mathrm{Am} \mathcal{J}$ Epidemiol 1987;126:237-46.

20 Berrino F, Crosignani P, Riboldi E, Viganò C. Epidemiologia dei tumori maligni: incidenza e mortalità in provincia di Varese: 1976-1977. Notizie Sanità, Regione Lombardia, 1981:1-53.

21 Berrino F, Crosignani P, Gotta G, Macaluso M, Pisani P, Viganò C. Incidenza dei tumori e cause di morte in Lombardia. Notizie Sanità, Regione Lombardia, 1986:1-95.

22 Gafà L. Registro dei tumori di Ragusa: mortalità ed incidenza 1981-1984. Assessorato Sanità Regione Siciliana e Lega 1981-1984. Assessorato Sanità Regione Sicilian
Italiana per la lotta contro i tumori, 1987:1-63.

23 Vasen HFA, Mecklin JP, Meera Khan P, Lynch HT. The International Collaborative Group on Hereditary NonPolyposis Colorectal Cancer (ICG-HNPCC). Dis Colon Rectum 1991;34:424-5.

24 Morton NE, Rao DC, Lalouel JM. Methods in genetic epidemiology. Basel: Karger, 1983:62-9.

25 Edwards JH. The simulation of mendelism. Acta Genet (Basel) 1960;10:63-6.

26 Warthin AS. Heredity with reference to carcinoma as shown by the study of the cases examined in the patholoshown by the study of the cases examined in the pathological laboratory of the University of Mid

27 Mecklin JP. Frequency of hereditary colorectal carcinoma. Gastroenterology 1987;93:1021-5.

28 Chapman I. Adenomatous polyps of large intestine: incidence and distribution. Ann Surg 1963;157:223-6.

29 Antoni Bombi J. Polyps of the colon in Barcelona, Spain. An autopsy study. Cancer 1988;61:1472-6.

30 Weisburger JH, Wynder EL. Etiology of colorectal cancer with emphasis on mechanism of action and prevention. In: De Vita VT, Hellman S, Rosemberg SA, eds. Important advances in oncology 1987. Philadelphia: Lippincot, ant advances 1987 : $197-220$.

31 Farber E. The multistep nature of cancer development. Cancer Res 1984;44:4217-23.

32 Lipkin M. Biomarkers of increased susceptibility to gastrointestinal cancer: new application to studies of cancer prevention in human subjects. Cancer Res 1988;48:23545.

33 Terpstra OT, Van Blankenstein M, Deeds J, Eilers GAM. Abnormal pattern of cell proliferation in the entire colonic mucosa of patients with colon adenoma or cancer. Gastroenterology 1987;92:704-8.

34 Ponz de Leon M, Roncucci L, Di Donato $\mathrm{P}$, et al. Pattern of epithelial cell proliferation in colorectal mucosa of normal epithelial cell proliferation in colorectal mucosa of normal subjects and of patients with adenomatous polyps
cancer of the large bowel. Cancer Res 1988;48:4121-6.

35 Deschner EE, Raicht RF. Kinetic and morphologic alterations in the colon of a patient with multiple polyposis. Cancer 1981;47:2440-5.

36 Fearon ER, Vogelstein B. A genetic model for colorectal tumorigenesis. Cell 1990;61:759-67.

37 Fearon ER, Cho KR, Nigro JM, et al. Identification of a chromosome 18q gene that is altered in colorectal cancers. Science 1990;247:49-56.

38 Vogelstein B, Fearon ER, Hamilton SR, et al. Genetic alterations during colorectal-tumor development. $N$ Engl ₹ Med 1988;319:525-32.

39 Vogelstein $B$, Fearon ER, Kern SE, Hamilton SR, Preisinger AC, Nakumura Y, White R. Allelotype of colorectal carcinomas. Science 1989;244:207-11. 